\title{
Labour Migration, Vulnerability, and Development Policy: The Pandemic as Inflexion Point?
}

\author{
Ravi Srivastava ${ }^{1}$
}

Accepted: 7 December 2020 / Published online: 18 January 2021

(C) Indian Society of Labour Economics 2021

This issue takes the current pandemic as a point of reference to reflect on the nature of migration processes in India which involve labour migrants who generally work in the lower rungs of the informal economy. It particularly focuses on the circular migrants who were hardest hit by the stringent lockdowns in India and abroad. While migration occurs for a variety of reasons and takes a number of forms, it mostly aims at improving the livelihood and employment prospects of the movers and supports the growth and development of the areas to which the movement occurs. But this does not happen without significant stress and costs. Patterns of unequal development, demographic changes, wars, and conflicts play a large role in migration. Overall, the global trend has been towards higher mobility, both between countries and within countries, although at various levels, the data is fuzzy. This has contributed to greater well-being and prosperity, notwithstanding the many stress points. However, migration is not a single phenomenon in terms of nature, distance, and temporality and migrant workers have diverse characteristics. Many are poor and have little or no skills or assets, and others are well placed and well endowed in skills and assets. The former have poor bargaining power, form segments at the lower end of the labour market at destination, and struggle to achieve basic rights. The diversity in characteristics is also shared by migrants moving within, and across, national boundaries.

Attempts to curtail or structure mobility are not new. This is obvious in the movement between countries since immigration controls and rules are available to sovereign countries. It is less obvious in the case of internal migration where constraints and barriers on specific types of migration mobility operate through higher economic and non-economic costs. Historically, short-term controls on pandemics such as the Corona-Cov-2 pandemic of 2020 have operated through checks on population mobility, which reduces spatial transmission risks (see de Haan in this volume). These restrictions have dramatic and negative consequences for the economy and for economically vulnerable populations. Among the vulnerable, migratory populations

Ravi Srivastava

ravisriv@gmail.com

1 New Delhi, India 
and refugees are likely to be deeply affected, but research and policies have a strong tendency to ignore the existence of such populations (De Haan 1999).

\section{International Migration}

Internal and international (including cross-border) migration is generally seen with different lenses. This is understandable because international migration is subject to a country's sovereign control over its borders and is permitted through its immigration rules. Moreover, the costs of international migration and information asymmetries are much higher, but benefits to migrants could also be higher due to higher wage/earning differential between countries. While there are also other differences, both internal migration and international migration are impelled by similar factorsin the case of economic migration, lack of adequate opportunities at source, or availability of better opportunities at destination; or in other cases, force of compulsion (as in the case of refugee migration or internally displaced persons (IDPs) ); or other factors (Srivastava and Sasikumar 2005; King and Skeldon 2010; Srivastava and Pandey 2017).

Globally, international migration is a greater focus of monitoring and policy attention for various reasons (Srivastava and Pandey 2017). The ILO and the UN have adopted a number of specific conventions and recommendations to protect the rights of international migrant workers, while the UN, the IOM, and the World Bank routinely monitor the trends in international migration and remittances. On the other hand, internal migrants and migrant workers are guaranteed their rights and protected against exploitation under the laws of the land and the general ILO Conventions which are deemed to be sufficient to protect their interests (ibid.). Compared to international migration, internal migration is only the subject of sporadic reports.

The impact of the pandemic has been severe on international emigrant workers, particularly low-skilled emigrant workers on short-term contracts working in the informal economy and undocumented workers. Loss of jobs, wage theft, issues with visa extension, closure of border crossings, lack of access to any social protection mechanisms, cost of repatriation have all taken a heavy toll on them. Incomes also declined for those emigrants who continued in employment. The ILO estimates that global labour income losses, without income support measures, declined by 10.7 per cent during the first three-quarters of 2020 compared to the same period in 2019 (ILO 2020).

The World Bank (Ratha et al. 2020) currently estimates that international remittances would decline by 7.2 per cent in 2020, followed by a further decline in 2021 . High return migration and low prospects of new emigration are estimated to cause an absolute decline in the total numbers of emigrants, more severe than the 2008 global crisis (ibid.).

For India, international migration is voluminous and India is the highest earner of international remittances, which, however, is projected to decline by about 9 per cent in 2020 (Ratha et al. 2020). On the other hand, India also has a significant volume of migration from other countries, although most of this from countries with which India shares a border (Srivastava and Pandey 2017). There is scanty literature 
on the impact of the pandemic on these migrants, whereas we know more about the actual and possible impact of the pandemic of international migrants, particularly worker migrants in the Gulf and other regions.

The broad pattern of Indian emigrants abroad was in the past dominated by middle and high-income states in the North, West, and South of the country. Over time, the pattern of worker migration tilted towards the Eastern states of the country-Uttar Pradesh, Bihar, and West Bengal (Srivastava and Pandey 2017). The pandemic with its impact on oil revenues is likely to have a significant impact on the GCC countries which depend on oil exports due to falling oil revenues. As Abella and Sasikumar (this issue) show in their paper, trends in aggregate worker emigration closely mirror, albeit with a lag, the growth trends in the Gulf economies. They point out that the Government of India's Vande Bharat mission brought back nearly 60000 stranded Indians from various countries abroad, of whom 170,000-180,000 were migrant workers. Since the journeys involved a direct travel cost of \$350-400, many workers could not avail of them. Nonetheless, the likely scenarios of employment loss on incomplete contracts or wage loss for those migrants continuing to be employed imply a loss of earnings for the migrants as well as a loss in remittances. This loss increases when the "sunk costs" of migration in terms of recruitment costs are factored in. Abella and Sasikumar consider the segment of low-skilled workers, migrating to Saudi Arabia to be engaged in the construction sector. Based on the distribution of length of contract and earnings of this group, they project estimated loss in earnings and remittances under assumptions of job loss or lower wages. They point out that two counter tendencies may imply that the actual decrease in remittances may not be as high as anticipated: first, the tendency of employed migrants to remit a higher proportion of wages during crisis, and second, that the loss in employment may eventually not be very high due to the irreplaceability of lowskilled migrants in some sectors.

The Southern state of Kerala continues to have a large stock of migrants abroadmore than two million, particularly in the Gulf states. Kannan and Hari, in this issue, offer a long-term view of emigration from Kerala and hypothesise the impact of the pandemic of emigration and remittances in Kerala. Migrant workers from Kerala are currently estimated to be about $17-18$ per cent of its workforce. Kannan and Hari estimates the number of migrants from Kerala and total remittances over nearly a half a century. Although emigration peaked around 2012-2013, remittances have shown a steady increase, but their contribution to state income declined from over a fifth at the beginning of this decade to about 14 per cent between 2015 and 2020, mainly due to a rapid growth in Kerala's state income. Significantly, the secular increase in remittances was not reversed either by the Gulf wars or by global economic crises, including the 2008 crisis. The fact that total remittances increased despite a decline in the total number of migrants, Kannan and Hari note, was due to the changing educational and skill composition of the emigrant workforce, with a much smaller proportion engaged in manual and low-skilled jobs. The paper also analyses the macro-economic implications of the emigration for the state economy over different phases, its impact on the labour market, on household income and consumption and (increasing) inter-personal inequality, despite the state's low multidimensional poverty index (MPI) and high human development index (HDI). The 
other negative aspect of Kerala's development is the persistence of educated unemployment, especially among women, despite the safety valve of emigration. The third negative aspect is the declining tax collection effort shown by the share in net state domestic product (NSDP) of own tax revenue. The paper notes that the economic crisis precipitated by the pandemic confronts the state with multiple challenges and possibilities. As far as emigration is concerned, the crisis could be a turning point in terms of a sharp decline in Kerala's large-scale labour migration to the Gulf countries, but alternatively, it could set off a beginning of a change in the composition of emigration if the demand for health care personnel increases in the Gulf as well as in other countries.

The Kerala migration story is examined from another perspective by Abraham (this issue), which can throw light on the long-term prospects open to return migrants affected by the current crisis (assuming that the short-term prospects could be overshadowed by the severity of the economic crisis and unemployment). Using the Kerala Migration Survey data, Abraham examines the occupational mobility of international migrants, pre-, during, and post-migration. Abraham points out that the major destination for migrants in Kerala is the GCC and 95 per cent of the migrations to the Gulf countries are on temporary contracts. Kerala still accounts for the highest Indian emigrant stock in the GCC. It is also the state with the highest return emigrant stock in India, and a high proportion of return emigrants are still in the working-age group and active in the labour force. The contractual jobs are mostly low skilled but offer a much higher earning potential to the migrants, although at the cost of deskilling for many, and downward occupational mobility. Their post-return occupational choices in the home labour market would be dependent on their level of human and physical capital and re-migration intentions, but termination or nonrenewal of the migrant's contract could have an adverse impact on the occupational choices of the return migrants.

Using data from the 2011 Kerala Migration Survey, Abraham constructs three mobility matrices over the three phases of geographical mobility of return migrants in the economically active age group. The study finds that skilled blue-collar workers are in a higher proportion in all three stages of migration and they along with elementary workers form the largest proportion of return emigrants in Kerala. However, the proportion of workers is twice in the service sector while abroad, as compared to in the source region. The proportion of higher-skilled workers (professionals, associates, and technicians) are more or less stable over the three phases, while there is a significant rise (from negligible) in the percentage of workers reporting as managers/self-employed post-return. The data show a high occupational persistence among pre-emigration and post-return occupational choices, indicating that work experience abroad does not lead to a significant level of occupational mobility for return emigrants in Kerala. Around a fifth of the return migrants show upward mobility, while ten per cent moved to a lower occupational category. Only about 10 per cent are engaged in self-employment (mainly as proprietors and managers). Thus, the paper concludes that international migration does not lead to upward occupational mobility for most migrants and that there is limited skill augmentation ensuing from foreign work experience. Understanding these occupational trajectories in "normal" circumstances is more crucial in the current pandemic situation, 
with high numbers of return migrants, also unable to complete their contracts and requires an urgent consideration about the reintegration strategies for the migrants in the local economy and labour market.

\section{Migration and Labour Circulation in India}

Once households are considered as a site of production and social reproduction, a site where multiple strategies of subsistence converge, and which is placed in a social and cultural setting of kinship ties and the village, circular migration by individuals becomes part of a household strategy with diversification at its core (Ellis 1998). Lucas and Stark (1985) and the new economics of labour migration literature seek to explain these decisions by a risk spreading within households. Chen and Fan (2018) suggest that, in addition, migration transition theory, social network theories, and dual labour market theories also provide an explanation of labour market circulation. Of these, only the last emphasises the production structure and demand. The economies of production and social reproduction are shared between the migrant and the non-migrant part of the household in an intricate manner, enabling employers to meet only the basic cost of reproduction of the worker over the employment period, contributing to much greater flexibility and cheapening of labour. This has led to theorisations which focus on the dynamics of capital accumulation, capital labour relations, and how they incorporate the production and care economies (Breman 1996 and 2019, Larche and Shah 2018).

Further, it may eventually be possible for migrants to take longer-term decisions, to migrate with their families, eventually even to uproot themselves almost entirely from their village settings. This has led to studies which explore changes in labour circulation over time and the decisions to migrate and settle permanently in urban areas (Chen and Fan 2018; Hu, Xu, and Chen 2011; Anh et al. 2012).

Labour migration may be seen as part of the larger phenomenon of labour mobility through which labour flows meet the requirements of spatially distinct regions. The larger phenomenon of labour mobility includes labour commuting at one end, and permanent migration, at the other. Circular migration falls between the two ends of this spectrum. The circular migration that is implied here may not have any fixity, in terms of location or temporality. It includes international migrants, cross-border migrants, or internal migrants.

Attempting to find a completely common ground between the various definitions of circular migration is not easy, and some parts of all definitions are debatable. Zelinsky (1971: 225-226) defines circulation as:

a great variety of movements usually short term, repetitive or cyclical in nature, but all having in common the lack of any declared intention of a permanent or long lasting change in residence.

According to Skeldon (2012), the term "circular" implies a temporary movement that involves return. However, it is also distinct from "return migration", as it implies more than just a single out-and-return movement to return at any time. Hugo (1982) further makes a distinction between commuting, defined as regular 
travel outside the village from 6 to $24 \mathrm{~h}$, and circular migration, involving continuous but temporary absences of greater than 1 day.

Circularity includes migrants who adapt the seasonality of production and employment in their villages to that in the destination locations-whether rural or urban. It also includes those migrants who have acquired a certain fixity of location in urban spaces and also those whose location changes with workplaces and who, therefore, return to their native villages only when work opportunities are exhausted or when they themselves need to recuperate. A single label-seasonal or short term-eludes the circular migrants. Studies in most cases have focused either on short duration or seasonal migrants or those whose stay away from home have no temporal fixity, and who Breman in this issue describes as footloose workers or as modern day nomadism, which ensures that the workforce at the bottom of the economy, shorn off social security, and protection, can be bought at the lowest possible price and only hired for as long as their services. On the other hand, studies in the urban informal economy and in slums and similar habitations have often focused on the circular migrant who is struggling to put a foot in and find herself a niche in the urban economy and civic spaces.

Lucas (2015) in a review of internal migration globally points out that there is a neglect of seasonal and temporary migration globally. Such a neglect can have serious welfare and development implications for countries.

Long-term migrants in cities comprise either those who totally belong to the urban milieu or have largely extracted themselves from their rural roots. It also includes those who are semi-permanent residents in urban areas but still are linked to their rural habitat, with or without a desire to return to it permanently. Breman suggests that migrants who do not come back to the villages other than for short visits enjoy higher and steadier income, usually originate from castes-classes higher up in the village hierarchy, and are equipped with better physical and social capital. Survey results do not permit a very neat categorisation between different types of migrants. The National Sample Survey Organisation carried out a survey of migrants in 2007-2008. The survey allows us to distinguish between (in)-migrants, long-term outmigrants from households (away for more than a year), and short-term outmigrants (those who were away for work for a period of more than one month but less than six months). Results have shown that both (in)-migrants and long-term outmigrants who happen to be much more concentrated in better socio-economic groups than the short-term outmigrants who happen to be predominantly concentrated in lower consumption quintiles are from Scheduled Castes/Scheduled Tribes or Other Backward Classes (Kundu and Sarangi 2007; Srivastava 2012). Yet, as discussed earlier the long-term outmigrants also form part of the precarious workforce in the informal urban economy (Srivastava 2020b).

The migration of those at the bottom of the workforce which is less motivated by choice and search for better opportunity than by the dearth of livelihood opportunities in their home areas is very much a result of unequal development (Srivastava 2011b; Srivastava et al. 2020b) which has led to an empirical demarcation between sending states and receiving states. In fact, as shown in Srivastava (2020b, Table 8), states sending long-term migrants and short-term migrants largely overlap. As per the data from the 2011 Census and the NSS Survey on Migration (2007-2008), most 
outmigrants originate in a few low-income states and mostly travel to a handful of middle- or high-income states. The major source states are Bihar, Uttar Pradesh, West Bengal, Odisha, Rajasthan, Madhya Pradesh, and Chhattisgarh, whereas the major destination states are Delhi, Haryana, and Punjab in the North (along with other areas in the Delhi National Capital Region), Maharashtra, Gujarat, and Goa in the West, and Andhra Pradesh, Tamil Nadu, Karnataka and Kerala in the South. Recent studies also indicate that there is an increase in migration from the Northeastern states and towards the Southern states (see Lusome and Bhagat, and Peter et al. in this issue).

However, as Breman rightly observes in this issue, the contrast between home states (sending migrants) and host states (receiving migrants) is too simple and should not be reified. Gujarat happens to be a state of both in-migration and outmigration, and it is not the only one. Breman(1996) and Breman (2009) show that the demand for outside labour is not necessarily caused by a lack of local supply and migrants are employed because they are cheaper and more docile. In fact, as shown in Srivastava (2020b) a large amount of short-term outmigration emanates from within the high-income states.

At a more general level, one can ask whether such migration leads to an improvement in the condition of the individual and the household, and if so, in what way. Evidence shows that remittances lead to an improvement in consumption and decline in poverty, but effects are linked to the initial endowments of migrants and their current position in the labour market (Srivastava 2011a). Bharti and Tripathi in this issue use the India Human Development Survey (IHDS) data for 2004-05 and 2011-2012 and analyse intergenerational mobility between father-son pairs, with and without remittances. They find no significant difference in the occupational mobility profile of the two types of households. Although this study is for all types of households, the results are likely to hold more for migrants at the bottom of the occupational ladder.

The seasonal, short duration, and footloose migrants have been analysed in a number of papers in this issue. The general conclusion is that these labourers are among the lowest substratum of workers, intensely exploited and denied a modicum of labour rights (Mishra; Breman; Adhikari et al. this issue), and changes in labour regulation have increased labour flexibility and non-standard employment without addressing issues of rights and dignity of labour, or the balance between capital and labour.

Breman, who has studied the footloose labour in Gujarat for over half a century, summarises his findings on footloose migrants as:

'modern day nomadism, which ensures that the workforce at the bottom of the economy, shorn off social security, and protection, can be bought at the lowest possible price and only hired for as long as their services are required.

Class-wise, they can be clubbed as either semi-proletarians equipped with meagre and low yielding means of production (land, tools, cattle) or proletarians who are fully dispossessed from such ownership and at risk of even having forfeited control over where and when to apply their labour power. Their social profiles are structured on the basis of their primary identities defined by caste (Scheduled 
Castes or Dalits, Other Backward Classes); tribe (Scheduled Tribes or Adivasis) or creed (Hindus or Muslims). All these distinct clusters are further subdivided into a broad and stratified repertoire of hierarchical differentiation.

From day one, they are marked as outsiders lacking local language proficiency and familiarity with the alien habitat and its social intercourse.

A drift between their place of origin and the work that entices them away, labour nomads are not without assertiveness. However, it is a resilience that does not amount to a joint platform of protest and resistance.'

Mishra, in this issue, has analysed the unfreedom of seasonal labour migration from the rain-fed regions of three districts in interior Odisha, one of the lowincome states of India. The paper historically traces the causes of dispossession of agrarian producers, ranging from land acquisition, peasant differentiation as agriculture commercialises, and rural distress and agrarian crisis. Rural labour that escapes distress is absorbed in an exploitative capitalist labour market through a network of social and economic structures which builds on the ethnicity, caste, gender, and tribal identity of the labourers. Capitalism uses these structures of discrimination to discipline and control labour. In the specific manifestations of migrant lives, the capitalist and non-/pre-capitalist forms of exploitation intersect and create conditions for "conjugated oppression" (Lerche and Shah, 2018).

The seasonal migration patterns in the study areas are quite diverse but dominated by inter-state family migration to brick kilns where migration is structured by the dadan system, in which advances given by sub-contractors or Sardars at around the festival of Nuakhali are used by labourers to settle old debts and defray current expenses. In return, labourers commit their labour, as a family unit, to work in the brick kilns, effectively bartering away their freedom and bargaining power. Overall, Mishra notes that despite some diversity, within and between the migration streams, there is a marked adverse inclusion, often characterised by unfreedom, of labourers at the bottom of the social and economic hierarchy, in capitalist production.

Bihar (along with Uttar Pradesh) has long been seen as the largest reservoir of migrant labour to many parts of the country. This migration again combines different streams and variations reflecting the initial social and economic endowment of the migrant's household and individual characteristics. Dutta, in this issue, follows up on a long tradition of village and migration studies, initiated nearly five decades ago by a group of researchers working with the legendary researcher, Pradhan H. Prasad. (Of this research team, A. N. Sharma and Gerry Rodgers continue this research right till the present day.) Although secondary data suggest that Bihar contributes the most to short duration outmigration, Dutta finds that most of the outmigrants in her study are long-term migrants. The number of cases where entire households have relocated is low. While about one in five individuals migrated from two-third of the households, migration, especially among low-status social groups and agricultural labourers, was male dominated. Shorter-term migration streams were dominated by migrants from the poorest regions, and those at the bottom of the caste and class hierarchy, and these also constituted the most precarious migration streams. Again, while on average, migrants' educational level was higher than non-migrants, 
migration streams at the bottom of the education spectrum were dominated by the most vulnerable social groups and poorest source regions. The person's social and economic status was closely intertwined with the migration trajectory, and despite long periods of migration, most migrants continued to be in precarious jobs and enjoyed virtually no access to social protection entitlements at destination.

Uttarakhand, a mainly hilly state, with a long history of outmigration, was part of Uttar Pradesh till 2000. Awasthi and Mehta in this issue write about the background of migration from this state and then focus on the profile of a sample of migrants who had returned to the State after lockdown. Long-term circular outmigration from the region again far outweighed short-term outmigration, and in many cases, the former had partially been replaced by permanent outmigration, reducing many villages in the hills to the status of "ghost villages". Turning to their survey of returnee migrants, they find that two-thirds had migrated to other states and nearly a similar proportion of all return migrants were recent migrants. A high, four-fifth of the returnees, were in regular wage/salaried jobs, while about a tenth each were selfemployed or casual workers, but the salaried jobs were low skilled, low income, and informal, which ended as soon as lockdown started.

A number of papers in this issue analyse the conditions of migrant workers from the vantage point of receiving states and regions. The paper by Jayaram and Varma in this issue analyses the conditions of migrant workers industrialised Gujarat with a focus on two cities-Surat and Ahmedabad-and three sectors-construction, textiles, and hotels. In Ahmedabad, the textile value chain ended with women home-based workers who received a fraction of the minimum wage. The condition for male migrant workers in the small and medium units varied with scheduled caste migrant workers at the bottom of the ladder as helpers and contract workers having no possibility of upward mobility. Female workers earned even less than the male counterparts. Safety hazards were high, and scheduled tribe migrants were hired by the medium size units to do the most unsafe jobs. In Surat, 70 per cent of the powerloom workers were from Odisha working on piecerates on long shifts and when the powerlooms shut during the lockdown, many were stranded without wages. In the construction industry in Ahmedabad, workers were drawn from tribal areas within the state or from adjoining states, such as Rajasthan or Madhya Pradesh, through contractors, who paid them an advance. Again as lockdown struck, many workers were stuck without wages. Migrant women were often hired as jodis or couples - as 1.5 labour units, leading to a large gender wage gap and a lack of control over incomes. Women often delivered their infants on worksites, without basic facilities, and return to work within 15 days of their delivery (Jayaram et al. 2019). In the hotel industry, low-caste workers were generally employed in menial and insecure jobs. Under lockdown, workers immediately lost jobs and living spaces and left worksites with large wage arrears from contractors, who claimed that they were unable to recover wages from the hotel employers. Across the sectors, unsafe working conditions and poor living conditions, high congruence between work and social status, including gender, and a large role for contractors and intermediaries, were common features.

Maharashtra continues to be the largest major destination state for labour migrants. The paper by Singh et al. presents labour market characteristics in the organised construction industry in the urban economic agglomeration around the 
state capital, Mumbai. The construction industry also draws the highest number of circular/seasonal migrants - nearly 40 per cent of the total, according to NSS and IHDS estimates and employment in the industry grew at a remarkable rate between 1983 and 2011-2012 (Srivastava 2018). The industry employs a very high proportion of migrants and informal workers who are engaged through a dense system of sub-contracting, obfuscating the legal responsibility of employers towards the engaged workers. The paper tries to unpack the term "employer" by reflecting on the national level labour legislations, viz. the Inter-State Migrant Workers (Regulation of Employment and Conditions of Service) (ISMW) Act, 1979, the Building and Other Construction Workers (Regulation of Employment and Conditions of Service) (BOCW) Act, 1996 and the Contract Labour (Regulation and Abolition) Act, 1970 applicable to the construction sector, complemented with findings from fieldwork to provide a concrete understanding of the labour sub-contracting process. The perpetuation of the contracting system to engage migrants, the authors argue, is to provide employers with highly flexible and low cost labour, and the system evades regulation. The responsibilities under the laws are divided between the "contractor" and the "employer" and take no cognizance of the web of relationships.

Kerala, which has been a major source state for outmigration to other states as well as international destinations, has now emerged as a major and attractive destination state as a result of labour market characteristics and demographic changes. The state has also relatively the most proactive migration policies. Peter et.al. (this issue) estimate that the state is currently home to about 3.5 million circular migrants. The state began to see a heavy influx of migrant labour from the 1990s, and much of this was from beyond the neighbouring states, such as Tamil Nadu. Peter et al. present an analysis of the sectors engaging migrants and the emergence of long-distance corridors, with migrant labour coming to Kerala from the Eastern, Northern and North-Eastern states (Assam, Odisha, West Bengal, Bihar, Jharkhand, and Uttar Pradesh). They suggest that, like the rest of India, the temporary migrants belong to socially and educationally disadvantaged poor agrarian communities, whose livelihood opportunities in their native places have been severely constrained by a multitude of factors including climate change, disasters like drought and floods, conflicts, and oppression.

Kerala is one of the few states which has had proactive policy for labour migrants (Srivastava 2020c, Peter et al., this issue). Some of these measures date back to 2008. However, Peter et al. point out that the welfare schemes and regulatory framework had limited reach among the migrants. Collective bargaining largely eluded them, so that wages, although higher than other states, remained lower than local wages. There was also the "othering" of migrant labour, and even the "guest worker" label, which connoted the welcoming status being given to them, was an unfortunate extraction from international migration, where such workers acquired differentiated and lower rights compared to local workers. They further analyse the measures taken by the state for labour migrants during the lockdown. The state was impacted early by the pandemic and reduced economic activity forced a large number of migrants to return home from mid-March even before the lockdown. With lockdown, the government tried to meet the food-related challenges faced by the labour migrants, with the help of the local community setting up community kitchens, with partial success. 
Large-scale efforts were made to disseminate awareness about the pandemic among migrants in their languages. Many residential shelters were declared to be in situ shelters, and some new shelters were also set up. Government efforts were strongly supplemented by the community and civil society organisations (CSOs). The paper points out that Kerala's strong decentralised institutional set-up and disaster preparedness also equipped it to take steps arising out of pandemic-related crisis for migrants. But the state also made several mid-course corrections in dealing with the migrant crisis.

The North-Eastern states in India share international borders with Bangladesh, Myanmar, China, and Bhutan. Migration patterns in these states are complicated since these states are both source and destination states for internal as well as international (cross-border) migration. Lusome and Bhagat (in this issue) use Census and other sources of data to analyse patterns of internal migration in these states, and the impact of the pandemic on return migration. The paper also presents a rich texture of migration for states within the region.

On average, about a third of the people in the region are migrants, compared to 37 per cent for the country, and the region saw a rise of 5 million in the migrant population between 2001 and 2011. But 60 per cent of migrants in the region were intra-district. Overall, international migrants comprised 2.5 per cent of all migrants, but they comprised more than two-fifth of the migrants from outside the state. The North and the Eastern part of the country each contributed a fifth of the migrants from outside the region. The region also records a little more than one million migrants from the states in the region to other states-comprising about 2.2 per cent of the region's population. A majority of these moved to states within the region, but about one-fourth migrated to six major agglomerations in other parts of the country. Within the country, migration from the region exceeds migration to the region and the pattern of migration has now shifted southwards. The paper estimates that during the pandemic, post-lockdown, nearly half a million persons returned to the North-East which was also about half the total estimated stock of migrants in other parts of the country. Most of these migrants were engaged in the unorganised sector of the economy and lost their jobs during the lockdown.

\subsection{Gender in Circular Migration}

While women outnumber men in internal migration in India, it is often identified as part of marriage or associational migration (Srivastava 2012; Rajan and Sumeetha 2020; Mazumdar, Agnihotri and Neetha 2013). This generalisation is one of the inherent reasons for the invisibility of female labour migrants. While marriage and associated migration are part of the social practice of patrilocality, increased care work responsibilities are core reasons for the majority of women withdrawing from the labour force. Rajan et al. (this issue) argue that among circular migrants, the vulnerability of women falls into several categories, first, where single male migrants leave women and children behind, and the major responsibility of economic and social reproduction falls on these women, second, where women migrate with men, joining the labour force or 
taking up care responsibilities at home, and third, where women migrate singly to join the workforce. In each of the last two cases, women workers are part of the lower end of the informal economy, where their contribution as workers remains invisible and unrecognised, and their access to social protection entitlements remains weak.

Dasgupta's paper uses ethnographic material to analyse the situation of informal women migrant workers who work in the lowest rungs of the informal economy. Her fieldwork is based in the National Capital Region of Delhi which is also one of the largest urban economic agglomerations in which a large number of circular labour migrants are employed. Dasgupta focuses on two important sectors: domestic workers and construction workers. Her paper examines how migrant women workers organised their productive-reproductive responsibilities as construction workers and domestic workers. Of the women on whose narratives this paper is based, most had migrated from villages, and two from small villages and four-fifth were from Scheduled Castes or were Muslims. For most of the women, the migration to the NCR is as what is described as associational migration. The patterns of migration varied-some were settled construction workers, others were more short duration migrants, and most domestic workers planned to stay in the cities for a few years without any plan to stay there permanently.

Social networks and ties played an important role in finding the women a place in the labour market, even when clientelist ties were reproduced through petty contractors, or patriarchal relationships reproduced when women chose to work in the proximity of their husbands, given the incidence of worksite sexual violence. Women organised their employment and care responsibilities in a continuum using multiple strategies, depending on working hours, distance, support available from older siblings, or other relatives both at workplaces (in construction) and at home. Long working hours compromised their ability to bargain for better working conditions. Women who were spending more time in the city made choices about leaving older children in the village for schooling because of their own uncertain lives in the cities. The villages partially helped the families to reproduce and gave them a translocal existence.

The construction sector activity was, in principle, regulated by the Building and Construction Workers' Welfare Act (BoCW Act), whereas there was no sectoral law for domestic workers. Labour markets in both sectors were fragmented and segmented, and wages and working conditions were decided locally. Women workers in construction were deployed in multiple activities but treated as a pool of low-skilled labour with no chances of upward mobility. Workers across sectors did not get weekly leave or sick leave. None of the construction workers accessed maternity benefits under the BoCW Act. The labour contractors' presence in construction sector made invisible the capital owner from the workers. Social and economic institutions were closely intertwined in producing the specific characteristics of women's employment as well as the inter-linkage between employment and her care responsibilities, while at the same time keeping features of her work and exploitation invisible and underestimated.

\subsection{Commuting Labour}

As we remarked at the beginning of this section, labour commuting constitutes one end of the spectrum of labour mobility and, apart from availability of more 
remunerative jobs, is increasingly influenced by the patterns of urban economic growth, particularly the growth of urban economic agglomerations, cost of living in urban locations, and improved roads and means of transport. Bhatt, Chandrashekhar, and Sharma, in this issue, estimate that in 2018-2019, 18.8 million individuals living in rural areas were working in urban India, for 2.3 million urban workers, the place of work was rural and 9.7 and 7.8 million rural and urban workers, respectively, had no fixed place of work. Among all rural workers, 7.3 per cent were rural-urban commuters, while only 2.1 per cent of urban workers were urban-rural commuters. Using data from the Periodic Labour Force Survey (PLFS) for 2018-2019, the paper offers a rich analysis of the factors that influence commuting, which can be seen to complement decisions to migrate. The analysis of the detailed characteristics of commuters shows that rural-urban commuters are present in manufacturing and construction, wholesale and retail trade, transportation and storage, and education and that men are much more than women, and among men, the younger age cohorts were more likely to commute. The other detailed characteristics are not discussed here, and the reader may refer to the paper for further details. The authors also estimate a multinomial regression model for rural and urban areas, respectively. One of the caveats of the paper is that only place of residence and place of work (rural/ urban/no fixed place) are mentioned, while distance of commuting is not given, and the data would capture both daily commutes and short-term outmigration, but this again does not undermine the basic results, given the fluidity and complementarity of different types of labour mobility.

\section{Magnitudes, Despite Lack of Exactitude}

Lucas (2015), in a global review, points out that, due to inherent difficulties, given the fluidity of circular migration, circular (internal) migration is poorly measured. This is undoubtedly true for India. But over a period of time, evidence has accumulated about the large and growing numbers of circular migrants, providing little justification for their non-inclusion in policy.

Figures from the Census and NSS are often uncritically used to present very low and misleading estimates of short duration circular migration. The Census of India provides decennial figures of internal migrants (450 million in 2011 or about 37.7 per cent of the total population (Srivastava 2020d)). It further provides numbers of migrants by reason, distance, and duration. The NSS surveys on migration also provide estimates of short duration migration. But it has repeatedly been shown that these figures cannot be used to estimate even short duration circular migration (Srivastava 2020d).

Despite the uncertainty regarding numbers, alternative estimates have been made for short duration migration, based on NSS and IHDs surveys (NSSO 2010; Srivastava 2011a; Srivastava, Keshri, Gaur, Padhi and Jha 2020a). These studies also bring out the association of short duration circular/seasonal migration with low social status, poverty, low levels of education, etc. (see also Kundu and Sarangi 2007; Keshri and Bhagat 2012). Two Commissions and Committees set up by government itself 
(NCEUS 2007 and MoHPA 2017) have also gone into various estimates of short duration seasonal/circular migration.

The Economic Survey for 2016-2017 brought about by the Finance Ministry of the Government of India devoted a full chapter to migration flows. Using a Cohortbased Migration Metric, it estimated that annual inter-state labour mobility averaged 5-6 million people between 2001 and 2011, or a decadal inter-state migrant population of about 60 million and an inter-district migration as high as 80 million. Further, it estimated internal work-related migration using railways data for the period 2011-2016 indicating an annual average flow of close to 9 million people between the states. Further, based on Census estimates, the Survey claimed that during the period 2001-2011, the annual rate of growth of labour migrants nearly doubled relative to the previous decade.

In a study of the construction industry, Srivastava (2018) showed that the NSS significantly underestimated inter-state circular migrant workers in the industry. Further, in the wake of the pandemic and the migrant exodus, Srivastava (2020b) has attempted to provide estimates of vulnerable circular migrants, focusing on interstate migrants. The paper estimates that there are about 58.5 million short-term circular migrant, of whom 28 million are estimated to work in other states and 24 million in the urban areas of other states. Further, categorizing outmigrants in NCO groups 5-9 as being occupationally vulnerable, the paper estimates that there were 69 million vulnerable long-term circular migrant workers, of whom 24 million were inter-state migrants workers, and 19 million worked in urban areas of other states. Thus, the paper concluded that there was an estimated 52 million vulnerable interstate migrant workers, of whom 43 million were located in other states.

\section{The Current Pandemic and Circular Migrants}

India responded to the pandemic from February 2020 onwards through screening of international passengers and announcing preventing measures. On 19 March, the Prime Minister announced one-day voluntary lockdown as a preparatory measure. But this was followed by a three-week country-wide lockdown from the midnight of 24 March, announced only at four-hour notice. The lockdown did not take into account the country's economic structure or social demography. It addressed the middle classes when the Prime Minister evocatively asked citizens to treat their doorstep as a boundary ("Lakshman Rekha") and not to cross it during the lockdown (Breman, this issue). Only essential services were allowed to function during this period. All other economic activities came to a grinding halt.

The extreme restrictions on mobility affected the poorest who had to access essential services (drinking water and toilets) away from their houses. The severe restrictions which placed India at the top of the Oxford University's stringency index were considered essential to control the virus's transmission and to give time for the public health infrastructure to be strengthened to respond to the pandemic. But it left the poor and the migratory populations high and dry. Many millions of people, men, women, and children-footloose migrant labour, students, tourists, and others-were stranded in different locations, often without food, shelter, and money. 
The plight of India's migrant labour during the lockdown has been well documented in a number of rapid surveys carried out by civil society organisations on the ground who had been in close contact with migrant labour communities before and during the lockdown. The SWAN network was one such network of activists set-up during the pandemic, which created channels through which migrant workers in distress reached out to volunteers, who then channelled support through their network. The network was able to collect data on the distressed migrants and put out three reports. The data collected have been analysed for this issue by Adhikari et al. (this issue).

The government announced a package of measures for the poor on 27 March, but the circular migrants were by and large not covered by the transfer of limited amounts of cash to women account holders through accounts opened since 2015 to push financial inclusion, or to farmers, and poor pension holders in a government social assistance programme (Srivastava 2020b). Even the Public Distribution System (PDS) which ostensibly covers three-quarters of the rural population and half the urban population could not reach them. The paper documents that between March and July, even with some improvement over the weeks, only 18 per cent of the stranded migrants who reached out to them were able to access food rations. Across four states-Delhi, Haryana, Karnataka, and Maharashtra, only about 36 per cent had received assistance in the form of cooked food (Adhikari et al., this issue).

Short-term labour migrants often live in worksites and depend on contractors for payments. In many cases, payments for work carried out were also denied to them, but workers were held back at sites. Payment during lockdown was even rarer. Among nearly 24,000 workers whose data were available with the SWAN network, only 4 per cent said that they had been paid during lockdown, while 12 per cent that they had been paid partially. But in many cases, these payments related to work done before the lockdown (Adhikari et al., ibid.).

The footloose labourers who were ultimately dependent on meagre cash savings and uncertain food handouts, were eager to return to their villages. But the desperation was not limited to short-term migrants. Long-term migrants in India's urban economy, who had lost their jobs and earnings, and in many cases, were unable to pay their rents and were also left out of the social protection net and also felt that they had no recourse but to fall back on their rural resources (see below).

The exodus of the migrants began in the first week of lockdown, but the severe governmental response pushed them back to their shelters or they interned in government shelters. But there was no containing these migrant workers once there was news of an extension of the lockdown. Millions of workers, often accompanied by their family members, including young children began walking back to their villages-often thousands of miles away. They also used whatever means they could muster-bicycles, pushcarts, hired passenger or transport vehicles to make these journeys (Srivastava 2020b). As Adhikari et al. point out in this issue, the scenes were reminiscent of Steinbeck's depiction of mass movements of the poor during the Great Depression, or the movement of people in the Indian sub-continent during partition. At least 900 people died during these journeys.

Nearly half the distress calls to the SWAN volunteers emanated from migrants who had less than a day of food supply available with them (ibid). Nearly 57 per 
cent of the distress calls came from industrial workers (in factories or construction), where many of the former could have been longer-term migrants, about $8.65 \%$ belonged to the non-group based employed category and about $20 \%$ were self-employed and both these categories are more likely to have been longer-term migrants. The paper points out that initially a majority of distress calls were from short-term inter-state migrants.

Over a period of time, distress calls from longer-term migrants or "settled population" and intra-state migrants increased, indicating a widening net of vulnerability. The impact of the lockdown on longer-term circular migrants has also been corroborated by other surveys (Gramvaani 2020a and 2020b). Although these migrants had a better social network to tap into for loans or other forms of support, the loss of jobs and earnings of entire communities, in the face of the pandemic, and limited or no access to social protection programmes, exposed them to high risk and vulnerability. Once the lockdown was initiated, earners and remitters had to survive on savings, private or public assistance, reverse remittance from families in the villages, borrowing, and sale of assets. The scope for borrowing and sale of assets to finance subsistence or the journey back home was more likely to be available for long-term migrant workers than the footloose labour (Adhikari et al., this issue).

The harrowing journey home of the migrants was extensively captured by the Indian media, both print and visual. There were times in April-May when every highway in the country, South to North, West and North to East provided ample evidence of the large masses of migrants making their way home. The government stepped in only in early May, and then, too, there was lack of coordination between state governments and between states and the centre, regarding procedures and payments (Srivastava 2020b). While the government stated in the Supreme Court that by early June, nearly 10 million migrants had availed of trains and state provided transport to go home, the figures of migrants who travelled without any official support was much larger (ibid.). Moreover, despite instructions of the apex Court, a large number of migrants had to incur substantial costs in making the journey. The SWAN network found that 85 per cent of the migrant workers who had returned home or were in transit had to incur high costs for this journey (Adhikari et al. this issue).

The impact of the lockdown was particularly severe for women and children. Women workers and/or spouses faced inordinate problems in accessing health support during pregnancy and for other needs. Many were subject to severe forms of abuse in the confined spaces with spouses. Travelling back was an even more harrowing experience for them. Women were more likely to be thrown out of work during lockdown and less likely to be re-employed as lockdown relaxed (Adhikari et al. this issue).

The gender dimensions of the crisis have also been highlighted by Rajan et al.. Migrant women (workers or spouses) were subject to enormous hardship during transit, and some did not even survive the journeys. Job losses have been particularly severe among informal women workers, and regaining lost jobs has been more difficult for them, resulting in the widening of gender gaps. There was of increased evidence of domestic violence. Loans, debts, and accompanying poverty had resulted in instances of early marriages, sex trade, trafficking, exploitation, while bonded 
labour and child labour had emerged as areas of concern and may all be on the rise. There was also concern that it was increasingly difficult to meet the pre- and postnatal and pregnant requirements of women. Although the Ministry of Health and the National Commission on Women had issued an advisory on taking special care of women and children, their safety remained an area of concern.

Adhikari et al. (this issue) and Rajan et al. (this issue) also point out that while the extent of food insecurity, loss of livelihoods, and lack of medical care for migrants have been widely discussed, anxiety, fear, depression, and uncertainties concerning their life have received less attention. In particular, they point out that being in a cramped space with no work and constant uncertainty surrounding food spawned a mental health crisis. There has been some recognition of this in government and policy making circles. But the technocratic solutions avoided entire the socio-political context of the migrant crisis which had exacerbated the mental health trauma of the workers.

\section{Policy Implications}

Papers in this volume underscore the deep-seated vulnerability of labour migrants, neglect of migrants in politics, in policy, and lack of accepted place for them in cities. They approach policy issues largely from two perspectives-that of labour policy and labour regulation and that of social security and social protection. They have also highlighted political inclusion, and the importance of organisations of migrant workers. Most of these issues cut across countries and international and internal migrants (De Haan, this issue).

One of the reasons for the lack of neglect of migrants in the internal policy discourse is that they do not have a political constituency and that they are not able to exercise even the right to vote (De Haan, this issue). In the recent elections in the state of Bihar in India, the presence of migrant returnees put migrant-related issues firmly on the agenda.

The migrant crisis revealed that India's patchy social protection system does not address the requirements of the enormous mass of mobile workers in the informal economy. According to the ILO (cited by Rajan et al. this issue), India had the lowest percentage of population in Asia and the Pacific covered by at least one social protection benefit (effective coverage) in 2015. The social protection measures in place were more focused towards the rural population, leaving a much larger gap in covering the urban poor and migrant labour. The authors argue for a more migration-inclusive social protection policy encompassing public employment programmes, food, health, and cash transfer (Adhikari et al., Rajan et al., this issue). In their paper, Adhikari et al. (this issue) have argued for a bolstering of the two pillars of the relief response in India, viz. the Public Distribution System (PDS) and the National Rural Employment Guarantee Programme (NREGP). Authors have also argued for a comprehensive and universal social security and social protection system as recommended by the National Commission for Enterprises in the Unorganised Sector (NCEUS 2006, 2007). 
Ensuring social protection for migrants means not only creating these entitlements but also mechanisms to ensure that those programmes that exist can be accessed. This involves portability of entitlements such as the PDS, the right of children to attend schools, maternity entitlements of women, and nutritional and preschool education entitlements of young children (De Haan this issue). These social protection claims have been created by the national government, and some of them (such as PDS, nutritional entitlements of children, and attendance in schools) have been created by law, but cannot be exercised by migrants. There has been some progress in this direction-migrant children cannot be denied the right to enrol in schools for lack of documentation, and post-lockdown, the central government has promised portability of the PDS by June 2021 under its "One Nation, One PDS scheme".

But there are undeniable pitfalls in moving towards entitlements for migrants. First, social protection claims in India can be created by all three levels of government, central, state, and local and many claims that are created by lower level governments are only for their own citizens and exclude migrants under various domiciliary restrictions (Srivastava 2020a; MoHPA 2017; Kone et al. 2017). Second, portability would also require a system of registration of workers (and establishments), and transfer of provisions (registrations and claims) across jurisdictions. At present, no universal system of registration exists, and the reliance is on the system of identification created by government called the UID. This system has several flaws: it creates last mile exclusion of the most vulnerable, and it is susceptible to misuse (Breman, this issue). Any registration system for social security/social protection should be consistent with data privacy, and the concerned law is still being debated in India.

Almost all papers in the volume have argued for a strengthening rather than a dilution of labour laws. The main objective of a labour reform agenda should be to bring about inclusive and equitable growth, ensure a fair distribution of gains in productivity between workers and owners of capital, ensure industrial peace through a responsive system of grievance redressal, eliminate job discrimination against migrants on the basis of caste, gender etc., reduce precarity of employment, and create a minimum floor of labour standards for workers. Jayaram and Varma argue that the migrant crisis could be seen as a direct result of the complete absence of labour governance architecture in the segments of the urban labour markets that employ them, fuelling impunity of employers to perpetuate extractive labour practices. They argue that a labour reform process must bring the protection of migrant workers to the centre of its agenda by strengthening institutional mechanisms for holding employers liable for violations of their labour rights.

Firms are currently able to evade regulatory responsibility towards workers by either not falling within the ambit of the organised (formal) sector, or if they do, keeping workers out of the regulatory framework through a maze of informal and sub-contracting relationships, as mentioned earlier. Jayaram and Varma point out there were as many as seven sub-contracting layers in their study of the construction sector. Migrant sub-contracted workers have no record of their employment relationship and do not even know who their principal employer is. Laws recognise either the principal employer or the contractor but do not take into account the maze of these relationships. The migrant workers, temporary and mobile, with no 
proper documentation, face an impossible task in negotiating their way through the labour conciliation and adjudication machinery or the criminal justice system, both heavily tilted towards employers (Jayaram and Varma, this issue). Papers in this volume point out that the labour law changes have constantly undermined efforts to fix responsibility on principal employers, and the role of employers is constantly obfuscated in value chains across different types of activities where contracting/subcontracting is involved. They argue that the common factor between diverse extractive labour practices across sectors is that the relationship between migrant workers and their employers or contractors remains in the extra-legal territory. The inability of workers to invoke employers' liability to provide for them as a statutory right leaves them with work relationships that are not legally regulated, but fragment and segment them based on social identities of caste, gender, and ethno-linguistic identity. Labour standards need to be maintained across the entire supply chain, where small margins push smaller manufacturers towards a race to the bottom. Jayaram and Varma argue for recognizing the big retailers/buyers as the principal employers with a graded system of compliance responsibility across the value chain.

The labour governance architecture does not recognise or respond to the complex intersection of informality, mobility, and caste- or gender-based discrimination that enables violations of migrant workers' labour rights. Several important laws, such as the Minimum Wages Act, Employee's Compensation Act, and the Bonded Labour Abolition Act, which are applicable to all informal workers, also remain unimplemented due to poor enforcement. The enforcement of labour regulation has been affected by the steady debilitation of the labour regulation and inspection system. Rather than relaxing employer compliances, simplification along with greater accountability in the system of inspections can be built on tripartite principles, through greater worker and civil society participation (NCEUS 2007; Jayaram and Varma, this issue). Opportunities for informal and migrant workers to register their own unions or ensure their participation in recognised unions through affirmative action would also improve the compliance environment.

The labour reforms process must initiate the comprehensive identification, recognition, and inclusion of the entire spectrum of non-standard employment (including home-based work, piece-rated work, and family-based labour) into the ambit of the formal legal-policy ecosystem. Wherever feasible, systems of firm registration and worker registration should be implemented, so that a direct identification and establishment of employment relationship is possible.

\section{Does the Pandemic Denote an Inflexion Point for the Precarity of Circular Migrants?}

The neglect of labour migrants in policies is not a benign neglect, arising due to their accidental invisibility, and lack of adequate information regarding migration flows and numbers. While its structural causes-unequal development and demographic imbalances-are undeniable, the present condition of migrant labour is deeply embedded in the pattern of capitalist development, and social-structural conditions in which the production and social reproduction of labour take place. Many 
of the papers in the present volume emphasise the role of social structure, and gender is maintaining what Shah and Lerche (2020) call "conjugate structures of exploitation". The partial reproduction and social reproduction of the worker and her/his family in the rural village, the separation of worker from her/his social milieu, and in the case of wage worker: the pattern of recruitment and deployment in labour markets which are segmented in various ways, create a pool of highly low cost and flexible labour which circulates place to place and between town and country. Srivastava (2016a, b) and Srivastava, Padhi and Ranjan (2020) point out how labour market informality and flexibility are increasing in India in the formal sector of the economy, while the informal sector is in any case almost entirely informalised. Srivastava (2019) also shows how labour market flexibility, informality, segmentation based on social structure, and labour circulation go hand in hand.

Concerns with the implications of the precarity of migrants based on their working conditions and living conditions were highlighted during the migrant crisis in India following lockdown, which several authors here and elsewhere have recognised as the largest exodus ever in conditions of crisis. The implications of these conditions were not restricted to the migrant workers and their families but were also felt by the entire population (since living conditions and forced mobility both could cause a worsening of the epidemic). Further, the impact of the sudden forced mobility had significant implications for economic activity both at destinations (from where the exodus took place) and the source areas.

Since, as discussed in Section 4, the Indian state first refused to acknowledge the crisis and then was forced to respond reluctantly to the humanitarian crisis, the question that we ask is whether the crisis constituted a point of inflexion in the migration question in India. A similar question can be asked with respect to international migrants, but for lack of space, we restrict ourselves to the vulnerable internal migrants in India.

A part of the answer became evident even in the period when the stringent lockdown began to unwind when state after state, almost on cue began to make changes in labour laws. Labour law falls in the concurrent list, and states can make amendment to the laws with the consent of the central government. They can also amend provisions by invoking special conditions under powers provided to them in the Acts. As many as twelve states made amendments to provisions in labour laws as soon as the lockdown began to unwind in May 2020 (PRS Legislative Research 2020a). The maximum number of changes concerned increase in working hours ranging from 10 to 12 hours per day, changes in maximum hours permissible per week, and in overtime payments (ibid.). The rationale provided was work stretching necessitated by social distancing, meeting of labour shortages, or simply labour market flexibility required by new investments. However, several states made far more sweeping changes in labour laws with exemptions for periods between 1000 and 1200 days, in the name of attracting new investments and creating employment. The most extensive changes were proposed by states with the same political dispensation as the centre. Two states, Uttar Pradesh and Gujarat, approved ordinances repealing the provisions of all labour laws, with some caveats. These changes affected working hours, industrial safety, grievance redressal, formation of trade unions and industrial bargaining, and even social security provisions (Srivastava 2020b; Shyamsundar and 
Sapkal 2020). Although made individually by states, the changes followed a clear template provided by the central government on the advice of employers (Srivastava 2020b; PIB 2020). States such as MP and UP, which made sweeping changes in the labour laws, specifically claimed that they would create employment opportunities for migrant workers. The claims of higher investment and employment even in normal times have been strongly contested (Srivastava 2016b; Bhattacharjea 2019). Jayaram and Varma point out that the proposed changes were applauded by industry associations because they benefit large industrialists who engage organised workforce in their factories, where workers' collective bargaining and the state's regulatory mechanisms are more effective.

Under protests from trade unions that the changes in working hours violated the ILO Convention on working hours and complaint made to the ILO, the ILO Director General wrote to the Government of India. ${ }^{1}$ In July 2020, the central government told the Parliamentary Standing Committee on Labour that it did not concur with the changes proposed by the States, ${ }^{2}$ and in October 2020, the apex court struck down the provisions in the Gujarat ordinance making changes in working hours in factories and stated quite clearly that the pandemic was not a "public emergency" in the sense implied by the legislation, and the provision could not be invoked by the Gujarat government to make changes in maximum working hours and overtime. Although all of this led to a partial roll back, it is noteworthy that the changes were proposed at a time when the migrant crisis was at its peak and its magnitude emanating from employment precarity was clearly evident.

Another part of the answer emerged in September 2020, when the government legislated three labour codes. Industrial Relations, Occupational Safety, Health and Working Conditions, and Social Security Codes amalgamating central legislations on the above subjects. Coming, as they did, after the migrants' crisis, they provide a lens on the government's treatment of the issues mentioned in the preceding section. ${ }^{3}$

The Inter-State Migrant Workmen (Regulation of Employment and Conditions of Service) Act has now been subsumed in the Code on Occupational Safety, Health and Working Conditions (in brief, OSH). The provisions of the Code on OSH and the Code on Social Security now suggest that the Codes provide greater visibility on inter-state migrant workers. Their definition has been widened in the Codes to include workers in establishments moving across state boundaries on their own, and, for certain provisions, even self-employed migrants. Further, for registration purposes, establishments will be required to report on inter-state migrants employed by them. The central and state governments will be required to maintain a database of inter-state migrants, and such migrants (including those self-employed) will be able to self-register on that portal. Employers/contractors engaging inter-state-migrant

\footnotetext{
1 Jha (2020)

${ }^{2}$ Gupta, Moushumi Das (2020) "Illegal to increase factory work hours from 8 to 12 - parliamentary panel to labour ministry". The Print. July 20. https://theprint.in/india/governance/illegal-to-increase-facto ry-work-hours-from-8-to-12-parliamentary-panel-to-labour-ministry/465004/

3 A useful summary of the changes can be found in PRS Legislative Research 2020b.
} 
workers in establishments employing ten or more such workers (double of the numbers in the subsumed act) will provide a journey allowance under certain conditions and provide suitable conditions from employers and social security, facility of an annual health check-up if prescribed by government (a new facility). Finally, the state government will ensure that the benefits provided for building and construction workers are portable, and the benefit of PDS is available to the worker either in the source or destination state. An analysis of these provisions shows that while, by making references to inter-state migrant workers in these provisions, the Codes make migrants more visible, very few of them are new, significant or mandatory. The Code on Social Security lays the framework for social security for all workers, including migrants. But no scheme, others than those already pre-existing, is provided for migrants.

It is, however, more significant that most provisions relating to inter-state migrant workers in the Codes are circumscribed by the major provisions relating to industrial relations, working conditions, etc., which are aimed at the removal of the labour protective framework would lead to the informalisation of the small fraction of organised workforce in the country, rather than encourage unorganised units to formalise (Shyamsundar and Sapkal 2020). They weaken the scope for legitimate industrial action and jeopardise the right to association and social dialogue. Further, all the Codes weaken an already debilitated inspection system which will no longer even be complaints based.

Following the steps taken earlier in 2018 in the central sphere, the Codes have introduced fixed term employment in all establishments. The employees will have the same wages and leave benefits as permanent employees in the same category and will also be entitled to applicable social security benefits, and pro-rata gratuity benefits if they are employed in an establishment for more than a year. But the fixed term employees will not be able to graduate to being permanent employees and hence will also be denied career progression, thus creating a cadre of permanently insecure employees, unlike the treatment of such employees in several other countries across the world (Srivastava 2016a). Fixed term employment, it is argued, would encourage employers to increase direct employment replacing employment through contractors. Yet provisions relating to contract labour have been further liberalised, and establishments and contractors dealing with less than fifty contract workers (compared to twenty such workers earlier) will no longer need any permission or registration. The Code on OSH further obfuscates the relationship between worker and employer and the responsibility of the latter by juxtaposing the definition of employer with the contractor (an issue raised by several of the contributors in this issue). Similarly, threshold levels for factories, standing orders on employment, permission for retrenchment have all been raised, significantly enhancing deregulation in all aspects of the labour market and pushing it towards greater flexibility and precarity. Given that circular migrants already form a very large chunk of such workers, this basic tendency is not likely to be reversed by the rather cosmetic references to (only) inter-state migrant workers in the Codes.

The new labour law architecture has been seen by the Indian government as a key factor in promoting competitiveness of industry, "ease of business", and (in the context of the pandemic) economic revival. Yet, as a number of authors 
have argued, these arguments are highly debatable as industrial competitiveness depends on much wider range of factors such as infrastructure and the broader policy environment (Sood 2020; Srivastava 2016b; Bhattacharjea 2019; Jayaram and Varma, this issue). The current changes are grounded in the logic of a "race to the bottom" and a "low" route to capitalist development, as several contributors in this issues and elsewhere (Srivastava 2011b, 2020b) have argued, tilting the balance further towards large capital (Sood and Nath 2020). Analysts have noted that during July-September 2020, while India's GDP contracted by 7.5 per cent, the real profit of listed companies increased by 25 per cent, and the share of real wages declined (Chenoy 2020). Although the crisis has increased the visibility of migrants, particularly inter-state migrants, in social protection policy, the policy changes aim at increasing flexibility and precarity. Unfortunately, there are no signs that the precarious conditions of circular migrants in India, who faced the brunt of lockdown and occupy highly disadvantageous positions in the labour market, will experience less precarious and less unsafe conditions as a result of these changes.

Acknowledgements I am grateful to Alakh Sharma for having given me the opportunity to edit this issue and to S. K. Sasikumar for his critical suggestions and significant contribution to its production.

\section{References}

Anh, N.T., J. Rigg, L.T.T. Huong, and D.T. Dieu. 2012. Becoming and being urban in Hanoi: Rural-urban migration and relations in Viet Nam. The Journal of Peasant Studies 39 (5): 1103-1131.

Bhattacharjea, A. 2019. "Labour Market Flexibility in Indian Industry: A Critical Survey of the Literature," Working Papers 296, Centre for Development Economics, Delhi School of Economics.

Breman, J. 1996. Footloose labour: working in India's informal economy. Cambridge: Cambridge University Press.

Breman, J. 2009. The great transformation in the setting of Asia. Public lecture to accept honorary doctorate. The Hague: International Institute of Social Studies.

Breman, J. 2019. Capitalism, inequality and labour in India. Cambridge: Cambridge University Press.

Chen, C., and C.C. Fan. 2018. Rural-urban circularity in China: Analysis of longitudinal surveys in Anhui, 1980-2009. Geoforum 93: 97-104.

Chenoy, Sajjid Z. (2020). "Canary in the coalmine". The Indian Express, December 6.

De Haan, A. 1999. Livelihoods and poverty: the role of migration. A critical review of the migration literature. Journal of Development Studies 36 (2): 1-47.

Ellis, F. 1998. Household strategies and rural livelihood diversification. Journal of Development Studies 35 (1): $1-38$.

Gramvaani. (2020a). Mobile Vaani: Survey of Resident Workers. https://drive.google.com/file/d/1GNiT smOJP9W4J-hdgZCNvHa7GgMggnSh/view Accessed November 2020.

Gramvaani. (2020b) Mobile Vaani: Survey of Migrant Workers. https://drive.google.com/file/d/1sCYW aow14pLN0osg8PMRH1PeoepN8-h-/view. Accessed November 2020.

$\mathrm{Hu}, \mathrm{F}$., Z. Xu, and Y. Chen. 2011. Circular migration, or permanent stay? Evidence from China's ruralurban migration. China Economic Review 21: 64-74.

Hugo, G.J. 1982. New Conceptual Approaches to Migration in the Context of Urbanization: A Discussion Based on Indonesian Experience. In Population Movements: Their Forms and Functions in Urbanization and Development. Edited by Morrison, P.A., Liege: Ordina Editions for the international Union for the Scientific Study of Population. 
ILO (International Labour Organization). 2020. ILO Monitor: COVID-19 and the world of work, Sixth Edition, Geneva, September 23, 2020. https://www.ilo.org/global/topics/coronavirus/impacts-andresponses/WCMS_755910/lang--en/index.html.

Jayaram, N., P.Jain and S. Sugathan. 2019. No city for migrant women: construction workers' experiences of exclusion from urban governance and discrimination in labour markets in Ahmedabad. Gender \& Development 27(1):85-104.

Jha, S. 2020. ILO reaches out to PM Modi over labour law changes in various states. Business Standard. May 26. https://www.business-standard.com/article/economic-revival/ilo-reaches-out-to-pmmod i-over-labour-law-changes-in-various-states-120052500335_1.html

Keshri, K., and R.B. Bhagat. 2012. Temporary and seasonal migration: Regional pattern, characteristics and associated factors. Economic and Political Weekly 47 (4): 81-88.

King, R., and R. Skeldon. 2010. 'Mind the gap!' integrating approaches to internal and international migration. Journal of Ethnic and Migration Studies 36 (10): 1619-1646.

Kone, Z. L., Liu, M. Y., Mattoo, A., Özden, C., Sharma, S. 2017. "Internal Borders and Migration in India”. Policy Research Working Paper 8244. World Bank Group. Development Research Group. Trade and International Integration Team. November.

Kundu, A., and Niranjan Sarangi. 2007. Migration, employment status and poverty. Economic and Political Weekly 42 (04): 299-306.

Lerche, J., and A. Shah. 2018. 'Conjugated oppression under contemporary capitalism: Class relations, social oppression and agrarian change in India', . Journal of Peasant Studies Taylor and Francis 45 (5-6): 927-949.

Lucas, Robert E. B. (2015). Internal Migration in Developing Economies: An Overview, The Global Knowledge Partnership on Migration and Development (KNOMAD) Working Paper 6.https://www. knomad.org/sites/default/files/2017-04/KNOMAD\%20Working\%20Paper\%206_Lucas_Internal\%20 Migration.pdf. Accessed November 2020.

Lucas, R.E., and O. Stark. 1985. Motivations to remit: Evidence from Botswana. Journal of Political Economy 93 (5): 901-918.

Mazumdar, I., I. Agnihotri, and N. Neetha. 2013. Migration and gender in India. Economic and Political Weekly 48 (10): 54-64.

MoHPA (Ministry of Housing and Poverty Alleviation) (2017). Report of the Working Group on Migration. Ministry of Housing and Poverty Alleviation. Government of India, New Delhi. http://mohua .gov.in/upload/uploadfiles/files/1566.pdf. Accessed 16 August 2020.

NCEUS (National Commission for Enterprises in the Unorganised Sector). 2006. Social Security for Unorganised Workers, Government of India. http://dcmsme.gov.in/Social\%20security\%20report. pdf.

NCEUS (National Commission for Enterprises in the Unorganised Sector). 2007. Conditions of Work and Promotion of Livelihoods in the Unorganised Sector, National Commission for Enterprises in the Unorganised Sector, Government of India and Academic Foundation, August, New Delhi.

NSSO (National Sample Survey Office) 2010. Migration in India, (July 2007-June 2008). Ministry of Statistics and Programme Implementation, Government of India, New Delhi. June.

Press Information Bureau. 2020. "Union Labour and Employment Ministry Will Take All Possible Steps to Help Mitigate Problems Faced by The Industry and The Workers Due to Lockdown Announced to Curb Covid-19 Pandemic," Ministry of Labour and Employment, 8 May, https://pib.gov.in/Press ReleasePage.aspx?PRID=1622243.

PRS Legislative Research. 2020a. "State Changes in Labour Law". https://www.prsindia.org/theprsblog/ relaxation-labour-laws-across-states. Accessed 01 July 2020.

PRS Legislative Research. 2020b. "Overview of Labour Law Reforms”. https://www.prsindia.org/billt rack/overview-labour-law-reforms.

Rajan, S.I., and M. Sumeetha. 2020. Women workers on the move. In Handbook of internal migration in India, ed. S.I. Rajan and M. Sumeetha, 408-414. Delhi: Sage.

Ratha, D., S. De, E.L. Kim, Plaza Kim, S. Plaza, G. Seshan, and N.D. Yamengo. 2020. Migration and development brief 33: phase II: COVID-19 crisis through a migration lens. Washington: KNOMAD-World Bank.

Shah, A. and Lerche, J. 2020. Migration and the invisible economies of care: production, social reproduction and seasonal migrant labour in India. Transactions of the Institute of British Geographers. https://doi.org/https://doi.org/10.1111/tran.12401 Accessed 31 July 2020.

Shyamsundar, K.R., and Sapkal Rahul. 2020. Changes to labour laws by state governments will lead to anarchy in the labour market. Economic and Political Weekly 55 (23): 205. 
Skeldon, Ronald. (2012). Going Round in Circles: Circular Migration, Poverty Alleviation and Marginality, International Migration, Vol. 50, Issue.3Anh, N. T., Rigg, J., Huong, L. T. T., and Dieu, D. T. 2012. Becoming and being urban in Hanoi: Rural-urban migration and relations in Viet Nam. Journal Peasant Studies 39 (5): 1103-1131.

Sood. A (2020). "The Silent Takeover of Labour Rights". The India Forum. December 4.

Sood, A., and P. Nath. 2020. Innocuous Mistakes or Sleight of Hand? Labour Law Changes. Economic and Political Weekly 55: 22-30.

Srivastava, R. 2011. Labour migration in India: recent trends, patterns and policy issues. The Indian Journal of Labour Economics 54 (3): 411-440.

Srivastava, R. 2011. Labour migration, inequality, and development dynamics in India: An introduction. The Indian Journal of Labour Economics 54 (3): 373-385.

Srivastava, R. (2012), "Internal Migration in India: An Overview of its Features, trends, and Policy Challenges". National Workshop on Internal Migration and Human Development in India Workshop Compendium Vol. II: Workshop Papers October 2012. New Delhi: United Nations Educational, Scientific and Cultural Organisation, and UNICEF India Country Office. ISBN 978-81-89218-45-4. pp $1-47$.

Srivastava, R. 2016. "Myth and reality of labour flexibility in india and what is to be done? The Indian Journal of Labour Economics. 59 (1): 1-38.

Srivastava, R. 2016. Structural change and non-standard forms of employment in India. Geneva: ILO.

Srivastava, R. 2018. "Building India brick by brick: labourers in the construction industry” Indian exclusion report 2017-18. New Delhi: Yoda Press.

Srivastava, R. 2019. Emerging dynamics of labour market inequality in India: Migration, informality, segmentation and social discrimination. The Indian Journal of Labour Economics 62 (2): 147-171. https://doi.org/10.1007/s41027-019-00178-5.

Srivastava, R. (2020a), 'Vulnerable Internal Migrants in India and Portability of Social Security and Entitlements' Centre for Employment Studies Working Paper Series. WP02/2020, Institute for Human Development, New Delhi.

Srivastava, R. (2020b) 'Understanding circular migration in India. Its nature and dimensions, the crisis under lockdown and the response of the state.' IIHD Centre for Employment Studies Working Paper 04/2020. https://www.ihdindia.org/Working\%20Ppaers/2020/IHD-CES_WP_04_2020.pdf .Accessed 16 August 2020.

Srivastava, R. (2020c) Integrating Migration and Development Policy in India: A Case Study of Three Indian States. Centre for Employment Studies Working Paper Series. WP03/2020, New Delhi: Institute for Human Development.

Srivastava, R. 2020. Internal migration in india: recent trends and patterns, vulnerability and policy imperatives. Delhi: Paper prepared for the UNFPA.

Srivastava, R., and A.K. Pandey. 2017. Internal and international migration in South Asia: Drivers, interlinkage and policy issues; Discussion Paper. New Delhi: UNESCO Office.

Srivastava, R., and S.K. Sasikumar. 2005. An Overview of migration in India, its impacts and key issues. In Migration and development: Pro-poor policy choices, ed. Tasneem Siddiqui, 157-216. Dhaka: The University Press.

Srivastava, Ravi, K. Keshri, K. Gaur, B. Padhi, and A.K. Jha. 2020. Internal migration in India and the impact of uneven development and demographic transition across states: A study for evidence based policy”. New Delhi: Institute for Human Development.

Srivastava, R., B. Padhi, and R. Ranjan. 2020. Structural change and increasing precarity of employment in India. In Development challenges of India after twenty five years of economic reforms, ed. N.K. Mishra. New Delhi: Springer Publication.

Zelinsky, W. 1971. The hypothesis of the mobility transition, geographical review 61, 219-249. Progress in Human Geography 17 (2): 213-219.

Publisher's Note Springer Nature remains neutral with regard to jurisdictional claims in published maps and institutional affiliations. 